\title{
KEPARIWISATAAN TERKAIT 4.0 DENGAN MEMANFAATKAN BIG DATA
}

\author{
Suwarni ${ }^{1}$, Heriyadi Rachmat, Awaludin Nugraha, Cipta Edyanat \\ Sekolah Pascasarjana Universitas Padjadjaran Program Studi Pariwisata Berkelanjutan \\ E-mail: upwceria@gmail.com ; E-mail: heryadirachmat220@gmail.com
}

\begin{abstract}
ABSTRAK
Peranan data sangat penting terutama memasuki era ledakan data atau "Big Data". Oleh karenanya, pihak yang mampu mengolah dan memanfaatkan data-data yang bervolume besar, cepat berubah, variatif, dan kompleks, dapat mengambil keuntungan yang besar. Mengacu pada manfaat besar yang dapat ditawarkan oleh teknologi Big Data, menarik untuk melihat sejauh mana teknologi Big Data sudah dimanfaatkan di Indonesia, khususnya di bidang Pariwisata. Munculnya era tourism 4.0, merupakan dampak dari revolusi industri 4.0 di sektor pariwisata. Era ini ditandai dengan adanya kemudahan akses atas informasi melalui media digital. Era tourism 4.0 juga menjadi penyebab munculnya fenomena pergeseran budaya siber dan visual pada wisatawan Indonesia, khususnya perilaku generasi milenial. Perusahaan Online Travel Agent seperti Traveloka, AirBnB, Ticket.com dan Pegipegi telah memanfaatkan penggunan Big Data untuk memberikan kemudahan dalam layanan tiket pesawat, hotel, tiket kereta dan wisata.
\end{abstract}

Katakunci: Tourism 4.0, Big Data

\section{TOURISM RELATED 4.0 WITH UTILIZING BIG DATA}

\begin{abstract}
The role of data is very important, especially in the era of data explosion or "Big Data". Therefore, the parties which are able to process and utilize huge volume, rapidly changed, varied, and complex data can take large advantages. Considering big potential offered by Big Data technology, it is exciting to research how Big Data has been implemented in Indonesia, especially in the field of Tourism. The emergence of the tourism 4.0 era, is the impact of the 4.0 industrial revolution in the tourism sector. This era is marked by the ease of access to information through digital media. The era of tourism 4.0 is also the cause of the emergence of phenomena of cyber and visual culture shifts in Indonesian tourists, especially the behavior of millennial generation. Online Travel Agent companies such as Traveloka, AirBnB, Ticket.com and Pegipegi have used the use of Big Data to provide convenience in airplane ticket services, hotels, train tickets and tours.
\end{abstract}

Key words; Tourism 4.0, Big Data

\section{PENDAHULUAN}

Pendekatan dalam revolusi industri 4.0 pertama kali disampaikan oleh Klaus Schwab dalam tulisannya The Fourth Industrial Revolution. Konsep ini menjelaskan lahirnya revolusi 4.0 yang ditandai dengan adanya perpaduan teknologi sebagai penyebab biasnya batas antara bidang fisik, digital, dan biologis. (Schwab dalam Lee et al., 2018). Tiga hal tersebut, oleh Schwab diidentifikasi masuk sebagai perubahan megatrends di era revolusi industri 4.0 (Schwab, 2016).

Seluruh perkembangan dan perubahan dari revolusi ini, berujung pada satu kunci yang sama, yaitu melalui pemanfaatan kekuatan digitalisasi atas informasi. Berangkat dari hal tersebut, konvergensi teknologi yang terjadi melalui pemanfaatan digitalisasi atas informasi, diistilahkan sebagai masa internet of things (IoT). Istilah ini diartikan sebagai hubungan antara berbagai jenis hal seperti produk, layanan, tempat, dan sebagainya dengan orang-orang. Hubungan ini terjadi melalui adanya pemanfaatan teknologi atas informasi yang diakses melalui beragam bentuk platform (Schwab, 2016).

Era IoT, menjadi salah satu penyebab banyaknya pergeseran dalam situasi social masyarakat di berbagai sektor penting dunia. Sektor pariwisata salah satunya. Di sektor pariwisata, era IoT berdampak pada munculnya transformasi digital yang menjadi penyebab lahirnya tren tourism 4.0. Tranformasi digital inilah yang mengubah keseluruhan siklus ekosistem kepariwisataan, termasuk menjadi penyebab bergesernya budaya siber dan visual pada wisatawan.

Melalui teknologi informasi, triliunan byte data diciptakan setiap hari dari berbagai sumber, seperti dari media sosial, sensor, video surveillance, dan smart grids. Lautan data ini mengarah pada satu terminologi Big Data. Data memiliki peran penting dalam pengambilan keputusan strategis. Oleh karenanya, pihak yang mampu mengolah dan memanfaatkan data-data yang tersedia dalam volume besar, keragaman variatif, kompleksitas tinggi dan 
kecepatan penambahan data yang tinggi, dapat mengambil keuntungan yang besar.

Istilah Big Data mulai muncul setelah Tahun 2005 diperkenalkan oleh O'Reilly Media. Namun sebenarnya penggunaan data dan kebutuhan untuk memahami data tersebut sebenarnya sudah ada sejak jaman dulu (Aryasa, 2015) Banyak pihak yang mencoba memberikan definisi terhadap Big Data (Chandarana, Parth, \& Vijayalakshmi, 2014) Dapat disimpulkan bahwa Big Data mengacu pada 3V: volume, variety, velocity, dan ada yang menambahkan unsur V lainnya seperti veracity dan value. Volume (kapasitas data) berkaitan dengan ukuran media penyimpanan data yang sangat besar atau mungkin tak terbatas hingga satuan petabytes atau zettabytes; variety (keragaman data) terkait tipe atau jenis data yang dapat diolah mulai dari data terstruktur hingga data tidak terstruktur; sedangkan velocity (kecepatan) terkait dengan kecepatan memroses data yang dihasilkan dari berbagai sumber, mulai dari data batch hingga real time, sementara karakteristik veracity (kebenaran) dan value (nilai) terkait dengan ketidakpastian data dan nilai manfaat dari informasi yang dihasilkan.

Pada Big Data, data terlalu besar dan terlalu cepat atau tidak sesuai dengan struktur arsitektur database konvensional. Sehingga untuk mendapatkan nilai dari data, harus digunakan teknologi untuk mengekstrak dan memperoleh informasi yang lebih spesifik.

Terminologi Big Data sering dikaitkan dengan data science, data mining, maupun data processing. Namun, Big Data melibatkan infrastruktur dan teknik data mining atau data processing yang lebih canggih dari sebelumnya. Dalam mengimplementasikan teknologi Big Data di suatu organisasi, ada 4 elemen penting yang menjadi tantangan, yaitu data, teknologi, proses, dan SDM (Aryasa, 2015).

\section{METODE}

Metode penelitian yang penulis gunakan adalah metode penelitian kualitatif adalah metode penelitian yang berlandaskan postpositivisme digunakan untuk melakukan penelelitian pada kondisi obyek yang bersifat alamiah, peneliti berperan sebagai instrumen kunci, untuk teknik pengumpulan data dilakuakn dengan gabungan observasi, wawancara dan dokumentasi, hasil data yang diperoleh cenderung bersifat data kualitatif, untuk analisis data bersifat induktif, dan dari hasil penelelitian secara kualitatif ini dapat merupakan temuan potensi dan masalah, keunikan obyek, makna suatu peristiwa, proses dan interaksi sosial, kepastian kebenaran data, konstruksi fenomena, temuan hipotesis. (Sugiyono, 2019).

Penelitian ini menggunakan pendekatan kualitatif untuk menjelaskan secara deskriptif respon sektor pariwisata Indonesia dalam menghadapi era tourism 4.0. Sumber data yang digunakan adalah data sekunder berupa dokumen kebijakan, hasil penelitian terdahulu, report, paparan, serta sumber sekunder relevan lainnya. Terkait hal tersebut, penelitian ini lebih bersifat desk research dalam melihat permasalahan untuk dibedah lebih dalam secara deskriptif analisis.

\section{HASIL DAN PEMBAHASAN}

Personalisasi data banyak digunakan di banyak di dunia bisnis pariwisata sekarang ini. Salah satu bisnis yang memanfaatkan data untuk improvisasi dan meningkatkan kepuasan penggunanya adalah bisnis travel. Di Indonesia bisnis travel konvensional semakin tergerus dengan adanya OTA (Online Travel Agent) Seperti Pegipegi dan Traveloka sudah melakukan hal tersebut. Keduanya memanfaatkan data untuk menghadirkan beberapa penawaran menarik dan juga membaca kebutuhan para penggunanya. Untuk segmen travel data diperlukan untuk melacak kebiasaan dan kebutuhan pengguna. Dengan demikian penyedia jasa travel bisa dengan mudah menawarkan sesuatu yang berkaitan, dekat, dan sesuai dengan apa yang dibutuhkan oleh pengguna. Dari segi bisnis di dalamnya (hotel, tiket, dan wisata) ini juga bisa menguntungkan. Karena mereka dapat menyasar langsung pelanggan dengan kriteria yang sama. Penyedia layanan travel di Indonesia seperti Traveloka dan Pegipegi terkait penggunaan data ini. Mereka percaya big data adalah kunci untuk memahami apa yang dibutuhkan bagi para pelanggan. Dengan menganalisis big data, mereka dapat mengetahui pola, trend, preferensi dan kebiasaan pelanggan sehingga kami dapat memberikan produk dan layanan terbaik yang sesuai dengan kebutuhan mereka yang disampaikan oleh Communications Executive Traveloka Busyra Oryza.

Hal yang senada juga diungkapkan pihak Pegipegi. Public Relations \& Media Office Pegipegi Devi Agustina bahkan mengandaikan data sebagai sebuah harta karun. Data tersebut dijadikan sebagai bahan untuk pengambilan keputusan untuk mengembangkan bisnis yang telah ada. "Setiap data yang ada di Pegipegi bagi mereka seperti sebuah harta karun. Data ini dapat menjadi referensi bagi manajemen dalam menyusun strategi pemasaran, membuat program promosi dengan partner, serta untuk memprediksi trend dan kebutuhan customer Pegipegi.

Meski dinilai banyak manfaatnya penerapan big data tidaklah mudah, setidaknya butuh investasi dan teknologi yang mumpuni untuk membangun teknologi yang mumpuni. Upaya mengoptimalkan big data di Traveloka misalnya, penerapan big data merupakan sebuah tantangan sehingga pihaknya perlu membangun sebuah tim yang solid baik untuk data engineering maupun software engineering. Orangorang di dalamnya pun disebutkan orang-orang berprestasi seperti lulusan mahasiswa unggulan yang berprestasi, alumni perusahaan Silicon Valley, dan beberapa ahli di berbagai bidang disiplin ilmu. 
Tidak jauh berbeda, Pegipegi pun dikisahkan telah mengembangkan sebuah sistem terintegrasi yang mampu meng-handle data-data yang ada untuk selanjutnya diolah untuk mendapatkan wawasan yang bisa digunakan sebagai pertimbangan sebelum mengambil keputusan. Apa yang dilakukan keduanya pun juga dilakukan oleh beberapa perusahaan level internasional yang berada di segmen travel. Selain itu, AirBnb juga menerapkan big data yang dikombinasikan dengan sebuah algoritma yang mampu mencocokkan preferensi host dan tamu sehingga bisa mendapatkan hasil yang memuaskan bagi kedua belah pihak.

Hasil pemanfaatan data Traveloka dan Pegipegi sudah beberapa kali mengeluarkan fitur atau layanan yang berdasarkan data-data yang dimiliki. Fitur tersebut beragam. Untuk Traveloka, buah analisis data dihadirkan melalui fitur Notifikasi Harga yang saat ini bisa ditemukan di aplikasi Android dan iOS mereka. Fitur ini menyuguhkan hasil olahan ribuan data harga tiket pesawat setiap harinya untuk dihadirkan ke pelanggan. Berkat kemudahan yang ditawarkan, saat ini fitur Notifikasi Harga merupakan salah satu fitur yang paling banyak digunakan pelanggan Traveloka.

Untuk Pegipegi, hasil dari analisis data membuahkan fitur personal newsletter yang disesuaikan dengan kebiasaan dan karakteristik pelanggan. Selain itu ada juga notifikasi promo dan penawaran paket wisata yang didasari data-data kebiasaan pelanggan-pelanggan mereka dalam bertransaksi. Memasuki era digital data-data digital seolah menjadi bahan bakar baru bagi bisnis, terlebih bisnis digital. Apa yang dilakukan Traveloka dan Pegipegi sangat mungkin juga diterapkan oleh perusahaan online travel lainnya.

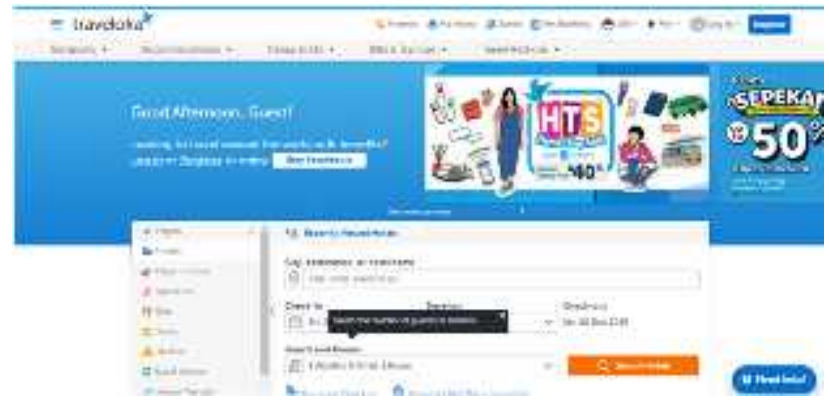

Gambar : Big Data Traveloka.com

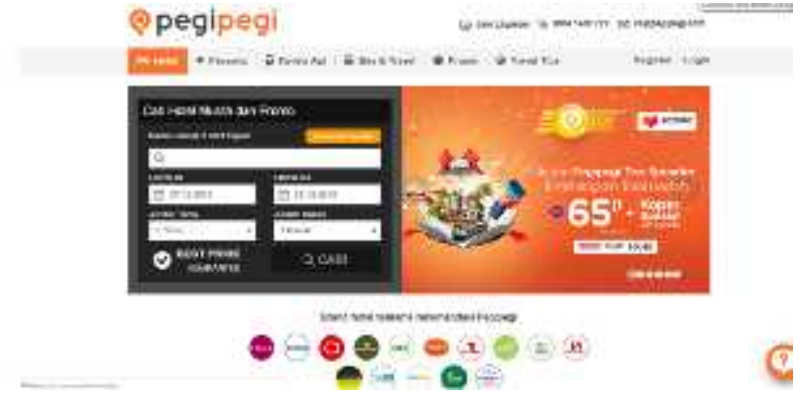

Gambar: Online Travel Agent Pegipegi.com

Sejak sepuluh tahun lalu, kegelisahan mulai melanda para pengusaha biro maupun agen perjalanan wisata nasional. Pasalnya, mereka meramalkan akan datang era digital yang bakal mendisrupsi model bisnis mereka. Betul saja, hari ini ancaman itu kian nyata dengan bermunculannya online travel agent (OTA) nasional maupun global, seperti Traveloka, Tiket.com, dan AirBnB yang menggerus pangsa pasar bisnis travel konvensional.

Kekhawatiran ini sangat lumrah mengingat besarnya pangsa pasar pariwisata di Indonesia. Menilik data Badan Pusat Statistik (BPS), pada 2017 ada sekitar 14 juta wisatawan mancanegara (wisman) dengan pengeluaran rata-rata sekitar Rp17 juta (kurs Rp14.155 per dolar AS), keseluruhannya setara Rp238 triliun. Lalu, ada 255 juta wisnus dengan pengeluaran rata-rata sekitar Rp700.000 yang keseluruhannya setara Rp178 triliun. Artinya, nilai pasar industri pariwisata Indonesia secara total mencapai Rp416 triliun. Jika ditelaah lagi, pangsa pasar ini juga turut diperebutkan oleh OTA. Salah satunya adalah Traveloka yang menawarkan berbagai tiket untuk keperluan liburan mulai dari pesawat, hotel, kereta, hingga atraksi dan berbagai aktivitas lain. Sejak meluncur pada 2012 lalu, perusahaan kini memiliki lebih dari 40 juta pengguna layanan dan lebih dari 14 ribu mitra hotel. Belum lagi pemain OTA lain, seperti Tiket. com dan TripAdvisory. Secara umum, 81\% wisatawan nusantara sudah menggunakan saluran digital (search engine, situs destinasi wisata dan OTA) dalam merencanakan perjalanan mereka.

Hal yang membuat OTA berkembang adalah yang tidak bisa dipungkiri yaitu perubahan perilaku wisatawan terutama generasi milenial yang selalu menginginkan kecepatan layanan, kemudahan layanan, dan harga yang murah telah memicu pertumbuhan OTA. Pangsa pasar OTA di Asia pada tahun 2017, termasuk Indonesia, diperkirakan telah mencapai US $\$ 146$ miliar atau setara $37 \%$ dari total pangsa pasar industri pariwisata di Asia sebesar US\$392 miliar (menurut riset Phocuswright dan CreditSwiss).

Perkembangan teknologi informasi dalam bisnis pariwisata sangat pesat. Travel Agent yang masih konvensial apabila tidak mengikuti pergerakan sistem teknologi informasi mereka bisa saja akan kalah dalam penjualan paket wisata maupun penjualan tiket pesawat karena semua sudah dikuasai oleh OTA (Online Travel Agent). Tekanan dari OTA makin 
terasa tatkala biro perjalanan wisata konvensional harus bersaing di level harga hotel dan pesawat. AirBnB, Agoda, dan Traveloka biasanya melakukan sistem blocking room night, yakni mereka membooking 1.000 hotel untuk satu tahun dan dibayar dimuka sehingga secara otomatis akan mendapat special rate. Perusahaan konvensional sulit bersaing karena kurang kuatnya modal. Alhasil, pangsa pasar ASITA (yang saat ini beranggotakan 7.000 perusahaan) di subsektor hotel hanya tinggal $10 \%$. Kondisi serupa juga terjadi di subsektor airlines. Dengan margin yang makin menipis, kira-kira hanya 2 - 3\%, praktis membuat kebanyakan anggota ASITA tidak menjual tiket pesawat lagi

\section{SIMPULAN}

Era tourism 4.0 merupakan adaptasi dari digitalisasi atas pariwisata yang terjadi sebagai dampak munculnya revolusi industri 4.0. Sektor pariwisata dunia termasuk Indonesia, merespon hal tersebut sebagai konsekuensi dari perubahan ekosistem pariwisata yang semakin mengarah ke digital. Perusahaan OTA seperti AirBnB, Agoda, dan Traveloka serta Pegipegi telah memanfaatkan penggunan Big Data dan sangat populer karena perubahan sikap perilaku wisawatawan ataupun masyarakat yang menginginkan layanan akses yang cepat dan mudah di era industri 4.0.

Jika ingin tetap bertahan, industri harus mau beradaptasi dan mengikuti perubahan pola perilaku konsumen dan berorientasi pasar. Ada baiknya perusahaan konvensional mempertimbangkan pembuatan divisi digital, digital platform, atau produk dan paket baru yang bisa bersaing. Salah satu caranya dengan berkolaborasi (sharing economy) dan memanfaatkan kapasitas-kapasitas yang tidak terpakai yang paling penting adalah inisiatif dan kreativitas.

\section{UCAPAN TERIMA KASIH}

Terima kasih kepada Keluarga Besar sda...SMK Negeri 1 Karanganyar dan Teman-Teman DPC ASITA Surakarta .

\section{DAFTAR PUSTAKA}

Sugiyono, (2019). Metode Penelitian Pendidikan (Kuantitatif, Kualitatif, Kombinasi, R\&D dan Penelitian Pendidikan. Bandung: Alfabeta

Lee, M., Yun, J., Pyka, A., Won, D., Kodama, F., Schiuma, G., ... Zhao, X. (2018). How to Respond to the Fourth Industrial Revolution, or the Second Information Technology Revolution? Journal of Open Innovation: Technology, Market, and Complexity, 4(3), 21.

Aryasa, K. (2015). Big Data: Challenges and Opportunities. In Workshop Big Data Puslitbang
Aptika dan IKP, tanggal 19 Mei 2015. Puslitbang Aptika dan IKP.

Chandarana, Parth, \& Vijayalakshmi, M. (2014). Big Data analytics frameworks: Circuits, Systems, Communication and Information Technology Applications (CSCITA). In International Conference on IEEE 2014. IEEE.

https://dailysocial.id/post/startup-travel-big-data https://www.wartaekonomi.co.id/read187696/ketika-otamendisrupsi-travel-agent.html 